\title{
THE APPLICATION OF SHARIAH (ISLAMIC LAW) IN SOME DIFFERENT COUNTRIES AND ITS IMPLICATIONS
}

\author{
Hyder Gulam ${ }^{1}$
}

\begin{abstract}
This paper will explore the meaning of Shariah and examines its application in specified countries around the world. The implications of the application on the development of Shariah will also be discussed by collating the writings of various scholars on the subject in the contemporary world. This paper will show that Shariah does not need formal legal recognition to be applied, as in the example of Australia where there is a Muslim-minority and there is no formal Islamic law. Other examples include the application of Shariah in Aceh and Singapore, which showcase a dynamic relationship between Islamic law and civil rulings. Shariah is supremely malleable and adaptable to many different situations and continues to evolve. By and large, the development of Shariah in non-Muslim states has shown that Muslims are readily able to comply with the laws of the land, while accommodating generally the various demands of religious legal obligations.
\end{abstract}

\footnotetext{
SQNLDR (ret) Hj Hyder Gulam FRCNA, FACN, Legal Editor Al Wasat Newspaper, Honorary Solicitor - Australian National Imams Council, Registered Nurse, Mediator, Barrister and Solicitor, BA, BN, LLB, LLM (ANU), LLM (Melb), MBA, Master of Islamic Studies (CSU), FRCNA, hyderg@yahoo.com
} 


\section{INTRODUCTION}

When Shariah (or Islamic law) is mentioned, the first image most people generally have is that of a violent capital punishment. However, as this study will show, Shariah is more than that, and like water in a desert, Shariah is more a means to achieving salvation in both the temporal life and the Hereafter. ${ }^{2}$ This paper is about how Shariah ${ }^{3}$ is applied in different countries around the Muslim world. The first part of this paper will define the key terms, following with an examination of the applications of Shariah in specified countries. The next part will comment on the implications of these application on the development of Shariah in the contemporary world.

\section{DEFINITIONS}

Shariah is based on the unqualified submission to the will of God (Allah). ${ }^{4}$ The will of Allah embraces all aspects of life and the law. ${ }^{5}$ Shariah is an Arabic word meaning 'the path to be followed'. ${ }^{6}$ Literally, it means 'the way to a watering place'. ${ }^{7}$ It is the path not only leading to Allah, but the path believed by all Muslims revealed through Allah's Last Messenger, Prophet Muhammad (peace be upon him). ${ }^{8}$ For adherents of Islam, Shariah governs every aspect of daily life and provides a moral and legal framework for Muslims; it does not separate religion from daily life, nor religion from politics, nor politics from morals, nor morals from the state. ${ }^{9}$

Unlike the European civil law or English common law, Shariah is considered to be divine in origin, and technically refers to a body of explicit revealed

2 M. Abdalla, 'Sacred Law in A Secular Law: To What Extent Should Shari'a Law be Followed in Australia,' Griffith Law Review, 21/3 (2012): 657.

3 Shariah, shari'a, syariah, shariat are transliteration from the Arabic script which refers to the divinely ordained law.

4 M.H. Kamali, Shar'iah Law: An Introduction (Oxford: Oneworld Publications, 2008).

5 C. G. Weeramantry, Islamic Jurisprudence: An International Perspective (Kuala Lumpur: The Other Press, 2001).

6 Laldin, M. A., Introduction to Shari'ah and Islamic Jurisprudence, $3^{\text {rd }}$ ed. (Kuala Lumpur: CERT Publications, 2011).

7 A. Rahman I. Doi, Shariah: The Islamic Law (Kuala Lumpur: A.S. Noordeen, 1984), 2.

8 A. Rahman I. Doi, Shariah: The Islamic Law.

9 Khatab, S. \& Bouma, G.D., Democracy in Islam (London, New York: Routledge, 2007). 
laws. ${ }^{10}$ Shariah is not strictly speaking a legal system, as the force and intent of its words and rules reach much deeper into thought, life, and the conduct than a purely legal system. ${ }^{11}$ The first and primary source of Shariah is the Qur'än (divine text of Islam). ${ }^{12}$ The second source is the Sunnah, the words and actions of the Prophet Muhammad (peace be upon him) as collected in the hadiths. ${ }^{13}$ The third source is both ijma' ' (consensus of opinion of 'ulama, or scholars) and qiyās (analogical deduction). ${ }^{14}$ Also available is e process of ijtihād or literally "striving, or self-exertion in any activity which entails a measure of hardship." 15 Ijtih $\bar{a} d$ is the process of making a legal decision by independent interpretation of the legal sources, the Qur'än, and the Sunnah. ${ }^{16}$ Fiqh (jurisprudence) is a related term that refers to 'knowledge of practical legal rulings derived from their specific evidence, as deduced from the Qur'ān and Sunnah to cover specific situations not directly treated in the revealed sources'. ${ }^{17}$ According to Professor Abdalla, unlike Shariah, fiqh is flexible and changes according to the circumstances under which it is applied. ${ }^{18}$ Muslims have agreed on the Shariah, but not on the rulings of fiqh. ${ }^{19}$

The higher purposes (or maqāsid) of the Shariah is to promote the good, to benefit human beings, and to protect them from evil. ${ }^{20}$ Sheikh Hisham Kabbani ${ }^{21}$ says that the primary objective of Shariah is 'mercy', and its foundation is

10 M. Abdalla, 'Sacred Law in A Secular Law: To What Extent Should Shari'a Law be Followed in Australia,' 657.

11 S. Khatab \& G.D. Bouma, Democracy in Islam.

12 M.H. Kabbani, 'Understanding Islamic Law,' Islamic Supreme Council of America, http://www.islamicsupremecouncil.org/understanding-islam/legal-rulings/52understanding-islamic-law.html, accessed 29 March 2016.

13 M. H. Kamali, M.H., Shar'iah Law: An Introduction (Oxford: Oneworld Publications, 2008).

14 Mehmet Ozalp, M., Islam between Tradition and Modernity: An Australian Perspective (Canberra: Barton Books, 2012).

15 M.H. Kamali, Principles of Islamic Jurisprudence (Cambridge: The Islamic Text Society, 2003).

16 M.H. Kamali, Principles of Islamic Jurisprudence.

17 M. Abdalla, M. 'Sacred Law in A Secular Law: To What Extent should Shari'a Law be Followed in Australia,' 657.

18 M. Abdalla, 'Sacred Law in A Secular Law: To What Extent Should Shari'a Law be Followed in Australia,' 657.

19 S. Khatab \& G.D. Bouma, Democracy in Islam.

20 Mehmet Ozalp, M., Islam between Tradition and Modernity: An Australian Perspective; M. H. Kamali, M.H., Shar'iah Law: An Introduction.

21 M.H. Kabbani, 'Understanding Islamic Law,' 
communal independence, in that no single person can carry out and fulfill the obligations of Shariah by themselves. Too numerous to list exhaustively, Shariah impacts upon the conduct of day-to-day life, politics, family, sexuality, hygiene, banking, business, contracts and social issues. ${ }^{22}$ A traditional legal system within a Western democracy, as currently prevails in Australia, is far less all-embracing than Shariah. ${ }^{23}$ The legal system in common law countries such as Australia regulates one's conduct in relation to other citizens (criminal law), the union and separation of couples (family law), trade and commerce between corporate entities, and many other areas of the individual's existence. Legal system like these (where there is no formal system of Islamic law) and Singapore (where there is a selective, hybrid system of Common and Islamic law), do not however impact upon the individual's private thoughts, deeds, lifestyle, or conduct to the same extent as that of Shariah. ${ }^{24}$

In terms of the application of Shariah, there are 57 self-declared Muslim countries as part of the Organisation of the Islamic Cooperation. ${ }^{25}$ A state is a member of the OIC if they are a member of the United Nations, having a Muslim majority and abiding by the OIC Charter. ${ }^{26}$ Of these, the numbers that have at least $55 \%$ of their population as Muslim are $41 .{ }^{27}$ Rehman and Askari $^{28}$ state that there are only the following declared Islamic countries: Afghanistan, Bahrain, Iran, Mauritania, Oman, Pakistan, Saudi Arabia, and Yemen. The following have declared Islam as the state religion: Algeria, Bangladesh, Egypt, Iraq, Kuwait, Libya, Malaysia, Maldives, Morocco, Qatar, Saudi Arabia, Tunisia, and UAE. This data reveals that even amongst Muslim countries, only a minority of Muslim states have declared Islam as their state religion. A state religion is the official or government-sanctioned

\footnotetext{
22 M.H. Kabbani, 'Understanding Islamic Law.'

23 N. Feldmen, 'Why Shariah?,' New York Times, http://www.nytimes. com/2008/03/16/magazine/16Shariaht.html?_r=2\&ref=asia\&pagewanted=all\&or ef=slogin, accessed 29 March 2016.

24 M. A. Laldin, Introduction to Shari'ah and Islamic Jurisprudence, $3^{\text {rd }}$ ed. (Kuala Lumpur: CERT Publications, 2011).

25 Organisation of Islamic Cooperation, http://www.oic-oci.org/oicv2/home/?lan=en, accessed 29 March 2016.

26 Organisation of Islamic Cooperation, http://www.oic-oci.org/oicv2/home/?lan=en, accessed 29 March 2016.

27 J. M. Otto, Sharia Incorporated: A Comparative Overview of the Legal Systems of Twelve Muslim Countries in Past and Present (Amsterdam: Leiden University Press, 2010).

28 S. S. Rehman \& H. Askari, 'How Islamic are Islamic Countries?' Global Economy Journal, 10/2 (2010), Article 2.
} 
establishment of a religion, but it does require the state be subservient to the power of a religion (as in a theocracy), nor is the state-sanctioned religion inevitably under the control of the state. ${ }^{29}$

\section{APPLICATION OF SHARIAH IN THE SPECIFIED COUNTRIES}

In reference to the application of Shariah the following countries were selected to provide a diverse overview: Australia is a Muslim-minority state, where there is no formal Islamic law $^{30}$ at one end of the spectrum; Aceh, as a state in Indonesia is an example of the application of Shariah in a modern setting, from the secular state of Indonesia, where Muslims predominate; and Singapore as an example of a secular state where, despite being a previously a Muslim majority, Muslims are now in the minority but the common law co-exists with Islamic law. ${ }^{31}$ However, there exists the application of Islamic law in the contemporary setting.

In countries where Islam is the predominant religion, the practice of Shariah and the practice of fiqh vary depending on the degree to which each respective state allows Islam to impact the function of the state and its courts. ${ }^{32}$ One example of an Islamic state is the Kingdom of Saudi Arabia (KSA), established in 1932, which is ruled by the House of Saud. Prior to the rise of the House of Saud, Saudi Arabia was part of the Ottoman Empire, with its millet system, as a means to accommodate the personal law of its different regions and religious denominations. ${ }^{33}$ The late King Fahd introduced a royal decree on 31 January 1992 which contained 9 chapters (83 articles) and provides in Article 1:

"The Kingdom of Saudi Arabia is a sovereign Arab Islamic state with Islam as its religion; Allah's Book and the Sunnah

29 J. Temperman, 'Are State Churches Contrary to International Law?' Oxford Journal of Law and Religion, 2/1 (2013): 119-149.

30 Hyder Gulam, 'The Historical Application of Shariah in Australia,' Al Wasat (October 2012).

31 Hyder Gulam, 'Islamic Law in Singapore,' Al Wasat (April 2015), https://hyderg. wordpress.com/2015/05/02/islamic-law-in-singapore-al-wasat-april-2015/, accessed 29 March 2016.

32 J. M. Otto, Sharia Incorporated: A Comparative Overview of the Legal Systems of Twelve Muslim Countries in Past and Present.

33 Ann Black, 'Accommodating Shariah law in Australia's Legal System,' Alternate Law Journal, 33/4 (2008): 214. 
of His Prophet, Allah's prayers and peace be upon him, are its constitution, Arabic is its language and Riyadh is its capital." 34

It is the Qur'ān and Sunnah of the Prophet which technically constitute the constitution of the KSA, and applied to its inhabitants irrespective of religion.

Another example of a country where Islam is widely practiced is the Republic of Indonesia. With a population estimated to be 255 million people and the world's fourth most populous country, Indonesia is the most populous Muslim majority nation. ${ }^{35}$ While not officially an Islamic state, approximately $88 \%$ or 200 million of the population identify themselves as Muslims. ${ }^{36}$ With independence in 1945 came the constitution, which set out the five nationalist principles or Pancasila devised by President Sukarno. ${ }^{37}$ The first of these five principles outlined in the Pancasila was a "Belief in the one and only God"; a compromise to help solve the conflict between Muslims, nationalists, and Christians.

The Jakarta Charter of the constitution contained a clear obligation for Muslims to follow Shariah, however this was never embedded into the Indonesian Constitution. ${ }^{38}$ Chapter 1 of the constitution specifically states that Indonesia is a unitary republic based on law with sovereignty in the hands of the people. Sovereignty is exercised through man-made laws. By chapter 11 of the constitution, the state guarantees religious freedom for all. ${ }^{39}$ Thus, in the broader Indonesian context, the application of Shariah was a light touch, with only monotheism being clearly articulated, due to the coalition of groups advocating for independence from colonial rule.

34 Ministry of Foreign Affairs, 'The Basic Law of Governance,' Kingdom of Saudi Arabia, http://www.mofa.gov.sa/sites/mofaen/ServicesAndInformation/ aboutKingDom/SaudiGovernment/Pages/BasicSystemOfGovernance35297.aspx, accessed 29 March 2016.

35 Central Intelligence Agency (CIA), 'World Factbook,' Government of the United States of America, https://www.cia.gov/library/publications/the-world-factbook. html, accessed 29 March 2016.

36 Statistics Indonesia (Badan Pusat Statistik), 'Population Census 2010,' accessed 29 March 2016.

37 Encyclopedia Britannica, 'Pancasila,' http://www.britannica.com/topic/Pancasila

38 N. Hosen, 'Religion and the Indonesian Constitution: A Recent Debate,' Journal of Southeast Asian Studies, 36 (2005): 419-440.

39 Wikipedia, 'Constitution of Indonesia,' https://en.wikipedia.org/wiki/Constitu tion_of_Indonesia 
However, the Indonesian state of Aceh formally introduced Shariah in 1999 as part of a peace treaty with the central government of Indonesia. ${ }^{40}$ This was part of a broader self governance framework, in religious and customary law, after decades of civil war. Of note was that not only were new Shariah regulations introduced which dealt mainly with the consumption of alcohol, gambling, and improper associations between members of the opposite sex, but the whole package included the implementation of Shariah courts, the Ulama Council, and the Shariah police. ${ }^{41}$

Feener $^{42}$ notes that the architects and institutional agents of Aceh's contemporary Islamic law system have gradually focused their attention and resources away from the promulgation of new laws and the prosecution of cases and toward strategies for the more informal 'socialization' of a particular set of Islamic values. This methodology has been made to work towards a more fundamental transformation of Acehnese society that extends well beyond black letter law (literal) and the state institutions of the formal legal sphere. Feener notes that in this, we find the legal program of Shariah implementation has been subsumed within a broader array of initiatives for reforming society in accordance with Islamic norms. ${ }^{43}$

Contra to the largest Muslim nation, in the Muslim minority states, the question is invariably about the extent in which a Muslim is obliged to follow Shariah in a non-Muslim country, ${ }^{44}$ of which Australia is such an example. Australia is a democracy with a multi-ethnic and multi-faith population in which Muslims are a distinct minority group; only $2.2 \%{ }^{45}$ Importantly, Australia's Muslim population is not as homogeneous as say Singapore or Indonesia, where the Malay ethnicity, language, culture and the Shāfi' $\overline{1}$ school

40 A. Feillard, 'Nahdlatul Ulama in Indonesia,' in The Oxford Handbook of Islam and Politics, ed. J. Esposito \& E. El-Din Shahin (New York: Oxford University Press, 2013).

41 R.M. Feener, 'Social Engineering through Shari'a: Islamic Law and State-directed Da'wa on Contemporary Aceh,' Islamic Law and Society, 19 (2012): 275-311.

42 R.M. Feener, 'Social Engineering through Shari'a: Islamic Law and State-directed Da'wa on Contemporary Aceh,' 275-311.

43 R.M. Feener, 'Social Engineering through Shari'a: Islamic Law and State-directed Da'wa on Contemporary Aceh,' 275-311.

44 M. Abdalla, 'Sacred Law in A Secular Law: To What Extent Should Shari'a Law be Followed in Australia,' 657.

45 Mehmet Ozalp \& Zulehya Keskin, 'Muslim Identity Threshold: Emergence of A Distinctive Australian Muslim Identity,' in Muslim Identity Formation in Religiously Diverse Societies, ed. D. Iner \& S. Yucel (Newcastle upon Tyne: Cambridge Oxford Scholars, 2015), 208-239. 
dominate. ${ }^{46}$ Authors such as Gulam ${ }^{47}$ have argued that religious systems such as Shariah and Judaic law do exist in Australia, but only informally, such Beth Din courts used by the Jewish community. Gulam argues that up until 1992, the "Muslim communities of Christmas and Cocos (Keeling) Islands in fact successfully managed their religious affairs and regulations using their Muslim personal and customary laws without any conflict with the Australian Family Law Act of 1975." 48

Black $^{49}$ also argues that Australia is already legally pluralistic, as official law co-exists with Islamic law in the form of Muslim personal law. The latter operates in the realm of the unofficial or the extra-legal, leaving it in a sphere of cultural practice. The problem with this, according to Black, ${ }^{50}$ is that this underground system lacks protections whereas official recognition is empowering. One important factor in this discussion is that the presence of Muslims from diverse nations in Australia means that their experience with Islam and Islamic law vary significantly. Professor Abdalla argues that Australian Muslims are by a large degree safe and secure to practice Islam freely, despite the fact that Islamic law does not prevail and Shariah does not shape or influence the Australian constitution. ${ }^{51}$

The senior 'ulama in Australia have also stated that commitment of a Muslim to Shariah does not conflict with their ability to abide by Australian law. ${ }^{52}$ Further, in Article 12 of the perspective on some key contemporary concerns, the 'ulama have clearly articulated that what the Shariah requires of a Muslim can be implemented without government regulation ${ }^{53}$ - for example: the five pillars of Islam, the need to stay away from sins or crimes which Islam

46 Hyder Gulam, 'Fiqh for Military Service: Guidance for Muslims in Australia,' Australian Defence Forces Journal, 192 (October 2013).

47 Hyder Gulam, 'Shariah and English Law,' Al Wasat (September 2012).

48 Hyder Gulam, 'The Historical Application of Shariah in Australia,' Al Wasat (October 2012).

49 Ann Black, 'Accommodating Shariah Law in Australia's Legal System,' 214.

50 Ann Black, 'Accommodating Shariah Law in Australia's Legal System,' 214.

51 M. Abdalla, 'Sacred Law in A Secular Law: To What Extent Should Shari'a Law be Followed in Australia,' 657.

52 NECIS (2015), 'National Imams Consultative Forum - An Australian Muslim Perspective On Some Key Contemporary Concerns,' National Centre of Excellence for Islamic Studies Asia Institute (University of Melbourne), nceis.unimelb.edu. au/about/projects/national_imams_consultative_forum, accessed 29 March 2016.

53 NECIS (2015), 'National Imams Consultative Forum - An Australian Muslim Perspective On Some Key Contemporary Concerns.' 
specifies, the ethical and moral values of honesty, fulfilling one's promises, and dealing with people gently and kindly.

Singapore has a population of almost 5.2 million, a majority of who are Buddhist Chinese. ${ }^{54}$ About 15\% of Singapore's population are Muslims, of which a majority are Sunni Muslim Malays, following the Shāfi'i legal school of thought. ${ }^{55} 17 \%$ of Muslims in Singapore are of South Asian origin and mainly of the Hanafì legal school of thougt. There are also Muslims in Singapore who are Shi' ite. ${ }^{56}$ Malays are the native inhabitants of Singapore, as recognized in the Singaporean Constitution, per section 152:

"The Government shall exercise its functions in such manner as to recognise the special position of the Malays, who are the indigenous people of Singapore, and accordingly it shall be the responsibility of the Government to protect, safeguard, support, foster and promote their political, educational, religious, economic, social and cultural interests and the Malay language."

Islam has been the dominant religion of the Malays in Singapore since the $16^{\text {th }}$ Century. By and large, given most Muslims in Singapore are Malays, they are generally homogenous and not as ethnically and culturally diverse relative to Muslims who form the minority in other countries, such as Australia, UK, Canada, etc. Singapore Muslims also share a very close bond to other Muslims in neighbouring states such as Malaysia, Indonesia, Brunei, Southern Thailand, and the Philippines. This create a distinct Malay community of largely shared values and perspective, independent from that cultural hegemony of the Middle East and North Africa, irrespective of sharing the same faith.

In Singapore, MUIS is the only authorized body sanctioned to issue fatawa (legal rulings) for the benefit of Muslims in Singapore. ${ }^{57}$ The Administration of Muslim Law Act, 1966 (AMLA) ${ }^{58}$ addresses the functions and jurisdiction of a number of key Muslim institutions in Singapore, including MUIS, as:

“... a statutory body to advise the President of Singapore on all matters relating to Islam in Singapore. It also has the role to see that the many and varied interests of Singapore's Muslim

54 Central Intelligence Agency (CIA), 'World Factbook,'

55 Central Intelligence Agency (CIA), 'World Factbook,'; Wikipedia, 'Islam in Singapore,' http://en.wikipedia.org/wiki/Islam_in_Singapore, accessed 29 March 2016.

56 Wikipedia, 'Islam in Singapore,'

57 A.N. Abbas, 'The Islamic Legal System in Singapore,' Pacific Rim Law and Policy Journal, 21/1 (2012): 167-187.

58 Administration of Muslim Law Act 1966 Singapore (AMLA). 
community are looked after in accordance with the principles and traditions of Islam as enshrined in the Holy Qur'an and Sunnah. " 59

MUIS has a Legal Committee consisting of the Mufti of Singapore, two other members of the Majlis and two non-members; the function of the Legal Committee is to issue fatawa on any point of Muslim law (AMLA, sections 30-33). AMLA sets out that in issuing any ruling, the Legal Committee shall ordinarily follow the tenets of the Shāfi 'ì school of law (AMLA, section 33). The MUIS website contains a number of important fatawa for the Muslim community in Singapore, some of which are unique to the circumstance of residing in the island state, such as $\mathrm{CPF}$ (superannuation) nomination, revocable insurance nomination, Zakat on Gold jewellery, matters of 'aqidah (creed) and religion $(d \bar{i} n)$, permissibility of organ donation etc. ${ }^{60}$ In summary, the MUIS Fatwa Committee adopts an inter-disciplinary approach in formulating fatawa, while keeping to Islamic tradition to ensure that the process is rigorous and serves the contemporary needs of the Singaporean community. In the Singaporean context, this approach is undertaken in harmony with the Common law. ${ }^{61}$

\section{IMPLICATIONS FOR THE DEVELOPMENT OF SHARIAH IN THE CONTEMPORARY WORLD}

As indicated earlier, Shariah impacts on the whole of a Muslim's life. ${ }^{62}$ It includes areas which are not the subject of control by the law in the secular legal environment. Arguably, the development of Shariah means looking back at the methodology of tradition and using modern techniques as a means of interpretation of the sources of Islamic law. This itself can vary from person to person and generation to generation, and even the Sunni schools of fiqh are divided into four schools or madhăhib. ${ }^{63}$ Puritanical Muslims believe in interpreting the Qur'an in the same way as when the Prophet Muhammad SAW was still alive, whereas moderate Muslims believe in an interpretation in accordance with current social norms ${ }^{64}$ In between the puritanical and the

\footnotetext{
59 Section 32, Administration of Muslim Law Act, 1966 (AMLA).

60 MUIS, 'Fatwa in Singapore - Office of the Mufti,' http://www.officeofthemufti.sg/ Fatwa/index.html, accessed 29 March 2016.

61 A.N. Abbas, 'The Islamic Legal System in Singapore,' 167-187.

62 S. Khatab \& G.D. Bouma, Democracy in Islam.

63 Recep Dogan, Five pillars of Islam (San Clemente: FB Publishing, 2015).

${ }^{64}$ K. Abou El Fadl, The Great Theft (New York, NY: Harper San Francisco, 2005), 17-132.
} 
moderate interpretations there are various other interpretations such as those of the secularists, conservatives, neo-traditionalists (or neo-fundamentalist), and reformers (neo-modernists). ${ }^{65}$ The methodologies that underlie these segmentation of the Muslim community, and their raison d'etre, are a key to understanding the development of Shariah in the contemporary world.

Layish ${ }^{66}$ argues that since the $19^{\text {th }}$ Century, Islamic law has gone through many changes, the main one being its transformation from a juristic law to a statutory law, the displacement of the 'ulama as its exclusive interpreters, and its secularisation and nationalisation through the judicial practice of the secular civil courts. In countries where Islam is the predominant religion, the practice of Shariah varies depending on the role of the form of governance; whether monarchy, democratic, or despotic rule. Throughout the Muslim world, Shariah and the practice of such law in its courts vary depending on the degree to which each respective state allows Islam to impact on the function of the state and its courts, along with the importation of legal techniques to deal with a modern economy. ${ }^{67}$

The dynamic development of Shariah in the contemporary world has seen its gradual development in non-Muslim majority states such as Australia, Canada, New Zealand, UK, USA etc. While this is not without obvious opposition, Nayed ${ }^{68}$ argues that living in 'many liberal environments' is actually more conducive to Muslims living and worshipping God than in so-called 'Muslim countries'. This 'liberal welcoming environment' is 'where a Muslim can freely practice his religion in which is he neither prosecuted not humiliated', an abode of peace. ${ }^{69}$ This leads one to ponder, whether when the universal teachings of Islam come together within the context of a Western country, does not only a unique experience of Islam emerge,${ }^{70}$ but rather does also an authentic and original form of Islamic law emerge. This is supported by a

65 John L. Esposito, Islam: The Straight Path (New York: Oxford University Press, 2005), 206.

66 A. Layish, 'Islamic Law in the Modern World,' Islamic Law and Society, 21 (2014): 1-33.

67 T. A. Alshubaiki, 'Developing the Legal Environment for Business in the Kingdom of Saudi Arabia: Comments and Suggestion,' Arab Law Quarterly, 27 (2013): 317-391.

68 A. A. Nayed, 'Duties of Proximity: Towards A Theology of Neighbourliness,' Global Centre for Renewal and Guidance (London) (Dubai: Kalam Research and Media, 2010), 4.

69 A. A. Nayed, 'Duties of Proximity: Towards A Theology of Neighbourliness,' 5.

70 Mehmet Ozalp \& Zulehya Keskin, 'Muslim Identity Threshold: Emergence of A Distinctive Australian Muslim Identity,’ 214. 
study on 'How Islamic are Islamic countries?' by Rehman, and Askari. ${ }^{71}$ The authors used an 'IslamicityIndex' to measure 208 countries adherence to Islamic principles using four sub-indices related to economics, law and governance, human and political rights, and international relations. The results showed that the Islamic countries were less Islamic in their practice than non-Islamic ones; where the top 35 were non-Islamic countries, and the highest Muslim country was Malaysia, at number 36. The upshot of all this, is that Shariah seems to be more true to form and spirit in non-Islamic countries. The other salient point is the unsaid conclusion that this research provides, namely whether Muslims actually need a formal system of Shariah to be implemented to be good Muslims and be true to its essential principles. As the senior Australian 'ulama have shown, the answer is clearly negative.

There are other countries with legal systems influenced to various degrees by Shariah. The types of Shariah in Aceh, Saudi Arabia, and Singapore vary distinctly in accordance with the degree to which these states embrace the Islamic faith. ${ }^{72}$ The development of Shariah in the modern world is a fluid concept that faces a number of internal challenges. The interpretation of Shariah varies according to whether the interpreter is Sunni or Shi'a. There are also various other factors which influence interpretation, ranging from legal school of thought to even gender. ${ }^{73}$ Even efforts to agitate for the limited application of Shariah in a Muslim minority states such as Australia is likely to trigger controversy not only between Muslims and non-Muslims, but even be a cause for dispute and disagreement among Muslims. ${ }^{74}$ One such controversy was in Canadian where one of the most vociferous objectors to the introduction of the limited form of a Shariah court was the Canadian Council of Muslim Women (CCMW). ${ }^{75}$

According to Hassan and Alhabshi ${ }^{76}$ when commenting on contemporary fiqh in Singapore, this aspect of Islamic law should contribute to the development

\footnotetext{
71 S. S. Rehman \& H. Askari, 'How Islamic are Islamic Countries?'.

72 J. M. Otto, Sharia Incorporated: A Comparative Overview of the Legal Systems of Twelve Muslim Countries in Past and Present.

73 H. H. Hassan \& S.T.S.A. Alhabshi, 'Contemporary Fiqh in Singapore: Some Observations,' Islam and Civilisation Renewal, 2/4 (2011)

74 Zwartz, B., 'Islamic Council Rejects Sharia Law Proposal,' The Age, 19 October, http://www.smh.com.au/national/islamic-council-rejects-sharia-law-proposal20091018-h2x9.html, accessed 29 March 2016.

75 Canadian Council of Islamic Women, http://www.ccmw.com/activitites/act_arb family faq.html, accessed 29 March 2016.

76 H. H. Hassan \& S.T.S.A. Alhabshi, 'Contemporary Fiqh in Singapore: Some Observations.'
} 
of the human intellect, and not to its stagnation and paralysis. Citing Sheikh Yusuf al-Qaradawi, Hassan and Alhabshi ${ }^{77}$ state that to issue fatawa solely on opinions contained in the old fiqh books inherited from previous centuries without any effort to observe the changing conditions of today is improper. This is argument articulated forcefully and coherently by Sheikh 'Abd Allah bin Bayyah. ${ }^{78}$ These efforts to contemporize fiqh cannot be regarded as bid'ah (innovation, which can be harmful or helpful) because it is equivalent to fiqh $a l$-waqi $i^{\text {' }}$ - understanding realities in formulating fiqh ruling, a concept that has been used by scholars since the earliest time. ${ }^{79}$ What this means is that the development of Shariah must meet the needs of the contemporary people and be open to new techniques and methodologies.

Extrapolating on this, that aspect of Islamic law that pertains to fiqh, one can see clearly the genesis and growth of fiqh of the minorities (fiqh al-aqalliyāt). Fiqh of the (Muslim) minorities was coined in response to the changing reality of the times. ${ }^{80}$ This is confirmed by the fact that the fiqh related to these minority groups is qualitative in nature and takes into account the relation of legal rulings to the conditions of a certain group living in a specific place in light of their particular circumstances, where what is suitable for them may not be suitable for others. ${ }^{81}$ The former respected Mufti of Egypt, Sheikh Ali Gomaa states that:

"The spatial circumstances of these minority groups affords them, in many instances, exigent justifications compelling a mufti to issue a fatwa (legal verdict) that is contrary to the established opinion of his school of jurisprudence, contrary to the opinion he deems dominant due to its evidences, or contrary to the fatwas of other muftis in areas where Muslims are the majority." 82

77 H. H. Hassan \& S.T.S.A. Alhabshi, 'Contemporary Fiqh in Singapore: some Observations.'

78 Hamza Yusuf, H. (2011). 'Muslim Living in Non-Muslim Lands,' [Speech by Sheikh 'Abd Allah bin Bayyah as transcribed by Sheikh Hamza Yusuf]. Retrieved from http://sunnah.org/articles/muslims_in_nonmuslim_lands.htm, accessed 29 March 2016.

79 H. H. Hassan \& S.T.S.A. Alhabshi, 'Contemporary Fiqh in Singapore: some Observations.'

80 M. Abdalla, M. 'Sacred Law in A Secular Law: To What Extent should Shari'a Law be Followed in Australia,' 657.

81 Ali Gomaa, 'An Introduction to the Fiqh of Muslim Minorities,' http://www.aligomaa.com/?page=scholary-output\&so_details=216, accessed 29 March 2012.

82 Ali Gomaa, 'An Introduction to the Fiqh of Muslim Minorities.' 
Both Sheikh bin Bayyah and Sheikh Gomaa argue that this particular fiqh of the minorities can help Muslim minority communities integrate into their wider community "without any dissonance between the rulings of their faith and the exigencies of life and in a manner that precludes any distress, hardships or oppression' which are rejected by the Shariah. ${ }^{83}$ As proclaimed in the Qur' $\bar{a} n:{ }^{84}$

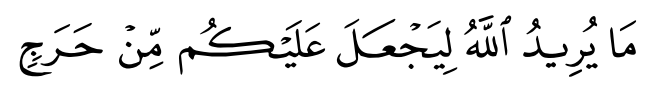

"God does not wish to impose any hardship upon you..."

(Surah al-Mā'idah, 5: 6)

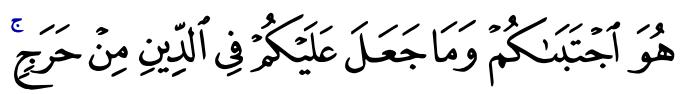

"He ... has not laid any hardship upon you in the Religion."

(Surah al-Hajj, 22: 78)

Other commentators, such Khatab and Bouma, ${ }^{85}$ posit that the Shariah acts as protective shield in defence of the rights and liberties of citizens against arbitrary power in those Muslim countries where Islamic law in enacted. The Shariah lays out the principles of good governance without prescribing its particular forms. ${ }^{86}$ This development of Shariah in the modern world sees the deep association between the rule of law and Shariah, where rulers of Muslim polity governed not as if they were above the law, but rather subject to it. ${ }^{87}$ This thrust in the development of Shariah in the modern world sees the gradual infusion of Islamic values and Shariah into existing political institutions. ${ }^{88}$ Elbayer goes further and notes that a number of Muslim countries are inserting 'Shariah supremacy' clauses in their constitutions, making any legislation which contradicts the provisions of Islamic law unconstitutional. This begs the

83 Ali Gomaa, 'An Introduction to the Fiqh of Muslim Minorities.' See also H. Dajani, (2015). 'Outdated Religious Law must be Changed, UAE Forum Hears,' The National (UAE) (29 April 2015), http://www.thenational.ae/uae/outdatedreligious-laws-must-be-changed-uae-forum-hears, accessed 29 March 2016.

84 This paper used the Ali Unal (2015) annotated interpretation of the Qur'än in modern English.

85 S. Khatab, S. \& G. D. Bouma, Democracy in Islam.

86 Mehmet Ozalp, Islam between Tradition and Modernity: An Australian Perspective.

87 N. Feldmen, 'Why Shariah?'

88 N. Feldmen, 'Why Shariah?' 
question, who's version of Shariah, and what methodology do they use for its interpretation ${ }^{89}$

What is readily discernible is the evolution of Shariah in the political landscapes of Muslim states, such as those impacted by the Arab Spring. In this vista, the tension points are based on the puritan versus the moderate Muslim conception of Shariah; notions about the source of legal reforms and the idea of the state. ${ }^{90}$ The result of the Arab Spring has been arguably a trigger for the call to implement constitutional reform in the form of Shariah precepts, ${ }^{91}$ in the hope that social justice and democratic values (such as the rule of law, full and free elections, meritocracy, and an end to corruption) will prevail. However, the challenge to this methodology is that it is a top down imposition, and does not build the civic society from the grass roots. The example of Aceh is one where the goal was social transformation, and not the mere implementation of religious legal devices and constitutional apparatus.

Conversely, while Professor Esposito sees a duality in the rise of democracy and Islamic resurgence (in the form of Islamic law), which he terms 'theodemocracy' in the Muslim world, he argues that it may also be subject to regression..$^{92}$ This revivalism has led to the clamor for the implementation of Islamic law, which Professor Esposito argues has amounted to superficial constitutional rendering rather than substantive change, leading to the regressive enactment of traditional punitive laws.$^{93}$ Elbayer argues that perhaps counterintuitively, it may be the spread of Islamic law within the Muslim world, rather than the replacement of Shariah with foreign system of law and governance, which will bring about the reform and revitalization that is sorely needed.$^{94}$ In this regard Professor Kamali states there is now a renewed emphasis on the goals of Shariah (the maqāsid, or higher objectives), with the express purpose of departing from the structures of literalism in the direction of a goal-oriented

$89 \quad$ K. Elbayar, 'Reclaiming Tradition: Islamic Law in A Modern World,' International Affairs Review, http://www.iar-gwu.org/node/23, accessed 29 March 2016.

90 J. M. Otto, Sharia Incorporated: A Comparative Overview of the Legal Systems of Twelve Muslim Countries in Past and Present, 39.

91 L. Sykiainen, (2013). 'The Arab Spring and Islamic Legal Thought,' National Research University Higher School of Economics (Higher School of Economics Research Paper No. WP BRP 17/LAW/2013 (April 2013), http://papers.ssrn.com/ sol3/papers.cfm?abstract_id=2258422, accessed 29 March 2016.

92 John L. Esposito, 'Islam and Democracy: Heritage and Global Context,' in Islam and Democracy, ed. J. Esposito \& J. O. Voll (New York: Oxford University Press, 1996), 11-33.

93 John L. Esposito, 'Islam and Democracy: Heritage and Global Context.'

94 K. Elbayar, 'Reclaiming Tradition: Islamic Law in A Modern World.' 
and comprehensive and holistic understanding of the sources of Shariah. ${ }^{95}$ It would seem then, that the more substantive and dynamic progress of Shariah in regards to its higher purposes is arguably coming from Muslim minority settings such as Australia. It is here, we are seeing the resurgence of ijtihād and expansive legal thinking, rather than being constrained by the dead hand of the past.

\section{CONCLUSION}

In conclusion, this paper has shown how Shariah is applied in different countries around the Muslim world, with particular reference to Australia, Indonesia, Saudi Arabia, and Singapore. This paper has commented on the implications of the findings herein on the development of Shariah in the contemporary world. This paper has shown that Shariah does not need formal legal recognition to be applied, as in the example of Australia where there is a Muslim-minority and there is no formal Islamic law. We have also described the application of Shariah in Aceh, a state in Indonesia as an example of the application of Shariah in a modern setting, as well as the application of Shariah in Singapore, an example of state where common law and Shariah co-exist formally. Shariah is supremely malleable and adaptable to many different situations and is continuing to evolve. By and large, the intriguing development of Shariah in non-Muslim states has shown Muslims readily able to comply with the law of the land, while accommodating generally the various demands of Shariah. Shariah is the glue that binds all Muslims as one, in worship of One God, and holding testament that Prophet Muhammad SAW is His last messenger.

\section{REFERENCES}

A. A. Nayed, 'Duties of Proximity: Towards a Theology of Neighbourliness,' Global Centre for Renewal and Guidance (London) (Dubai: Kalam Research and Media, 2010).

A. Feillard, 'Nahdlatul Ulama in Indonesia,' in The Oxford Handbook of Islam and Politics, ed. J. Esposito \& E. El-Din Shahin (New York: Oxford University Press, 2013).

A. Layish, 'Islamic Law in the Modern World,' Islamic Law and Society, 21 (2014): 1-33.

A. N. Abbas, 'The Islamic Legal System in Singapore,' Pacific Rim Law and Policy Journal, 21/1 (2012): 167-187.

95 Mohamed Kamali, Principles of Islamic Jurisprudence. 
A. Rahman I. Doi, Shariah: The Islamic Law (Kuala Lumpur: A.S. Noordeen, 1984), 2.

Ali Gomaa, 'An Introduction to the Fiqh of Muslim Minorities,' http://www. ali-gomaa.com/?page $=$ scholary-output\&so_details $=216$, accessed 29 March 2012.

Ali Unal (2015) annotated interpretation of the Qur'an in modern English.

Ann Black, 'Accommodating Shariah Law in Australia's Legal System,' Alternate Law Journal, 33/4 (2008).

C.G. Weeramantry, Islamic Jurisprudence: An International Perspective (Kuala Lumpur: The Other Press, 2001).

Canadian Council of Islamic Women, http://www.ccmw.com/activitites/act_ arb_family_faq.html, accessed 29 March 2016.

CIA (Central Intelligence Agency), 'World Factbook,' Government of the United States of America, https://www.cia.gov/library/publications/theworld-factbook.html, accessed 29 March 2016.

Encyclopedia Britannica, 'Pancasila,' http://www.britannica.com/topic/ Pancasila

H. Dajani, 'Outdated Religious Law must be Changed, UAE Forum Hears,' The National (UAE) (April 29th), http://www.thenational.ae/uae/ outdated-religious-laws-must-be-changed-uae-forum-hears, accessed 29 March 2016.

H.H. Hassan \& S.T.S.A. Alhabshi, 'Contemporary Fiqh in Singapore: Some Observations,' Islam and Civilisation Renewal, 2/4 (2011)

Hamza Yusuf, H. (2011). "Muslim living in non-Muslim lands". [Speech by Sheikh 'Abd Allah bin Bayyah as transcribed by Sheikh Hamza Yusuf]. http://sunnah.org/articles/muslims in nonmuslim lands.htm, accessed 29 March 2016.

Hyder Gulam, 'Fiqh for Military Service: Guidance for Muslims in Australia,' Australian Defence Forces Journal, 192 (October 2013).

Hyder Gulam, 'Islamic Law in Singapore,' Al Wasat (April 2015), https:// hyderg.wordpress.com/2015/05/02/islamic-law-in-singapore-al-wasatapril-2015/, accessed 29 March 2016.

Hyder Gulam, 'Shariah and English Law,' Al Wasat (September 2012).

Hyder Gulam, 'The Historical Application of Shariah in Australia,' Al Wasat (October 2012).

J. Temperman, 'Are State Churches Contrary to International Law?,' Oxford Journal of Law and Religion, 2/1 (2013): 119-149. 
J.M. Otto, Sharia Incorporated: A Comparative Overview of the Legal Systems of Twelve Muslim Countries in Past and Present (Amsterdam: Leiden University Press, 2010).

John L. Esposito, 'Islam and Democracy: Heritage and Global Context,' in Islam and Democracy, ed. J. Esposito \& J. O. Voll (New York: Oxford University Press, 1996), 11-33.

John L. Esposito, Islam: The Straight Path (New York: Oxford University Press, 2005).

K. Abou El Fadl, The Great Theft (New York, NY: Harper San Francisco, 2005).

K. Elbayar, 'Reclaiming Tradition: Islamic Law in A Modern World,' International Affairs Review, http://www.iar-gwu.org/node/23, accessed 29 March 2016.

L. Sykiainen, 'The Arab Spring and Islamic Legal Thought,' National Research University Higher School of Economics (Higher School of Economics Research Paper No. WP BRP 17/LAW/2013 (April 2013), http://papers. ssrn.com/sol3/papers.cfm?abstract_id=2258422, accessed 29 March 2016.

M. Abdalla, 'Sacred Law in A Secular Law: To What Extent Should Shari'a Law be Followed in Australia,' Griffith Law Review, 21/3 (2012): 657.

M. Ozalp, Islam between Tradition and Modernity: An Australian Perspective (Canberra: Barton Books, 2012).

M.A. Laldin, Introduction to Shari'ah and Islamic Jurisprudence, $3^{\text {rd }}$ ed. (Kuala Lumpur: CERT Publications, 2011).

M.H. Kabbani, 'Understanding Islamic Law,' Islamic Supreme Council of America, http://www.islamicsupremecouncil.org/understanding-islam/ legal-rulings/52-understanding-islamic-law.html, accessed 29 March 2016.

M.H. Kamali, M.H., Shar'iah Law: An Introduction (Oxford: Oneworld Publications, 2008).

M.H. Kamali, Principles of Islamic Jurisprudence (Cambridge: The Islamic Text Society, 2003).

Mehmet Ozalp \& Zuleyha Keskin, 'Muslim Identity Threshold: Emergence of A Distinctive Australian Muslim Identity,' in Muslim Identity Formation in Religiously Diverse Societies, ed. D. Iner and S. Yucel (Newcastle upon Tyne: Cambridge Oxford Scholars, 2015), 208-239.

Mehmet Ozalp, M., Islam between Tradition and Modernity: An Australian Perspective (Canberra: Barton Books, 2012). 
Ministry of Foreign Affairs, 'The Basic Law of Governance,' Kingdom of Saudi Arabia, from http:/www.mofa.gov.sa/sites/mofaen/ ServicesAndInformation/aboutKingDom/SaudiGovernment/Pages/ BasicSystemOfGovernance35297.aspx, accessed 29 March 2016.

MUIS, 'Fatwa in Singapore - Office of the Mufti,' http://www.officeofthemufti. sg/Fatwa/index.html, accessed 29 March 2016.

N. Feldmen, 'Why Shariah?,' New York Times, 16 March 2008, http://www. nytimes.com/2008/03/16/magazine/16Shariaht.html?_r=2\&ref=asia\&p agewanted=all\&oref=slogin, accessed 29 March 2016.

N. Hosen, 'Religion and the Indonesian Constitution: A Recent Debate,' Journal of Southeast Asian Studies, 36 (2005): 419-440.

NECIS (2015), 'National Imams consultative forum - An Australian Muslim perspective on some key contemporary concerns,' National Centre of Excellence for Islamic Studies Asia Institute (University of Melbourne). Retrieved from nceis.unimelb.edu.au/about/projects/national_imams consultative_forum, accessed 29 March 2016.

Organisation of Islamic Cooperation, http://www.oic-oci.org/oicv2/ home/?lan=en, accessed 29 March 2016.

R.M. Feener, 'Social Engineering through Shari'a: Islamic Law and StateDirected Da'wa on Contemporary Aceh,' Islamic Law and Society, 19 (2012): 275-311.

Recep Dogan, Five Pillars of Islam (San Clemente: FB Publishing, 2015).

S. Khatab \& G.D. Bouma, Democracy in Islam (London, New York: Routledge, 2007).

S. S. Rehman \& H. Askari, 'How Islamic are Islamic Countries?,' Global Economy Journal, 10/2 (2010).

Statistics Indonesia (Badan Pusat Statistik), Population Census 2010 accessed 29 March 2016.

T. A. Alshubaiki, 'Developing the Legal Environment for Business in the Kingdom of Saudi Arabia: Comments and Suggestion,' Arab Law Quarterly, 27 (2013): 317-391.

Wikipedia, 'Constitution of Indonesia,' https://en.wikipedia.org/wiki/ Constitution_of_Indonesia

Wikipedia, 'Islam in Singapore,' http://en.wikipedia.org/wiki/Islam_in Singapore, accessed 29 March 2016. 
Jurnal Syariah, Jil. 24, Bil. 2 (2016) 321-340

Zwartz, B. (2009). 'Islamic Council Rejects Sharia Law Proposal,' The Age, 19th October, http://www.smh.com.au/national/islamic-council-rejectssharia-law-proposal-20091018-h2x9.html, accessed 29 March 2016.

\section{Statutes}

Administration of Muslim Law Act (AMLA) 1966 Singapore. 